\title{
HUBUNGAN ANTARA PERAN DAN MODAL SOSIAL PEMANGKU KEPENTINGAN DENGAN PENGELOLAAN PARIWISATA BERBASIS KOMUNITAS PADA AGROWISATA ARGOAYUNINGTANI DI DUKUH PASAH DESA SENDEN KECAMATAN SELO KABUPATEN BOYOLALI
}

\author{
Rahmayani Dewi Setyowati ${ }^{1,}$ Dr. LV Ratna Devi Sakuntalawati, M.Si ${ }^{2}$ \\ Program Studi Sosiologi Fakultas Ilmu Sosial dan Politik \\ Universitas Sebelas Maret Surakarta Indonesia \\ Email: rahmayanidewis@ @student.uns.ac.id ${ }^{1}$, ratnadevi.solo@staf.uns.ac.id ${ }^{2}$
}

\begin{abstract}
This research aims to determine the correlation of stakeholder roles and social capital with community-based tourism management in Argoayuningtani agro-tourism in Hamlet Pasah, Senden Village, Selo District, Boyolali Regency. Theories used in this study are the Role Theory and Social Capital Theory. This research is a quantitative approach and uses survey methods. Data collection was carried out using the instrument in the form of a questionnaire, aimed at 60 respondents who were the population of the Argoayuningtani agrotourism manager. Data analysis using correlation statistics consisting of product moment correlations, partial product moment correlations and multiple correlations and assisted with the SPSS 20.0 program.
\end{abstract}

Based on the results of the study, it shows that the correlation of stakeholder roles with community-based tourism management is not pure, but must go through social capital variables as an intervening variable test factor. But within the population, the roles of stakeholders, social capital and community- based tourism management have a joint relationship. These results indicate that this research is in accordance with the theory of roles according to Bidlle \& Thomas and the theory of social capital according to Fukuyama. It can be concluded that community-based tourism management can work well if there are roles of stakeholders and social capital. It is different from previous research that community-based tourism management is only related to role, only with regard to social capital, while in this study it has a correlation.

Keywords: role, social capital, stakeholders, community based tourism, agro tourism

\begin{abstract}
Abstrak: Penelitian ini bertujuan untuk mengetahui hubungan peran pemangku kepentingan dan modal sosial dengan pengelolaan pariwisata berbasis komunitas pada agrowisata Argoayuningtani di Dukuh Pasah Desa Senden Kecamatan Selo Kabupaten Boyolali. Teori yang digunakan dalam penelitian ini adalah Teori Peran dan Teori Modal Sosial. Penelitian ini merupakan penelitian dengan pendekatan kuantitatif dan menggunakan metode survei. Pengumpulan data dilakukan dengan menggunakan instrumen berupa kuisioner, yang ditujukan kepada 60 responden yang merupakan populasi dari pengelola agrowisata Argoayuningtani. Analisis data menggunakan statistik korelasi yang terdiri dari korelasi product moment, korelasi parsial product moment dan korelasi ganda dan dibantu dengan program SPSS 20.0.
\end{abstract}

Berdasarkan hasil penelitian, menunjukkan bahwa hubungan peran pemangku kepentingan dengan pengelolaan pariwisata berbasis komunitas tidak murni, namun harus 
melalui variabel modal sosial sebagai faktor uji variabel intervening. Akan tetapi di dalam populasi, peran pemangku kepentingan, modal sosial dan pengelolaan pariwisata berbasis komunitas memiliki hubungan secara bersama-sama. Hasil ini menunjukkan bahwa penelitian ini sesuai dengan teori peran menurut Bidlle \& Thomas serta teori modal sosial menurut Fukuyama.

Dapat disimpulkan bahwa pengelolaan pariwisata berbasis komunitas dapat berjalan dengan baik apabila terdapat peran pemangku kepentingan dan modal sosial. Berbeda dengan penelitian terdahulu bahwa pengelolaan pariwisata berbasis komunitas hanya berkaitan dengan peran, hanya berkaitan dengan modal sosial, semenatara dalam penelitian ini kedua variabel tersebut memiliki hubungan.

Kata kunci: peran, modal sosial, pemangku kepentingan, pariwisata berbasis komunitas, agrowisata

\section{PENDAHULUAN}

Pariwisata dinilai menjadi peluang bisnis besar untuk mendorong perkembangan sektor ekonomi dari adanya wisatawan yang melakukan kegiatan wisata (Rizkianto, 2018). Data dari Badan Pusat Statistik (BPS) pada 2015 menunjukkan bahwa jumlah pendapatan devisa negara sebesar 12,225.89 Juta Dollar disumbang oleh sektor pariwisata.

Perjalanan wisata yang dilakukan wisatawan saat ini pun beragam, menurut Kemenpar (2016) tren wisata yang berkembang tak hanya melulu berwisata ke tempattempat umum dan terkenal saja atau biasa disebut wisata massal (mass tourism), namun pada dunia wisata saat ini berkembang pola perjalanan ke arah wisata alternatif (alternative tourism) yang banyak dipilih oleh wisatawan sebagai wujud dari kepedulian akan isu kelestarian lingkungan dan komunitas lokal. Pengembangan wisata di pedesaan dinilai menjadi alternatif pilihan yang baru dan dipandang menjadi hal strategis untuk pembangunan pariwisata (Rizkianto, 2018).

Data dari Kementrian Desa dan Daerah Tertinggal menunjukkan bahwa Indonesia memiliki lebih kurang 74.000 desa di seluruh nusantara (https://pddi.kemendesa.go.id/). Beragam keunikan baik berupa lanskap maupun kearifan budaya masyarakat dimiliki oleh tiap-tiap desa tersebut, tentu saja ini merupakan sebuah modal mahal nan potensial untuk dunia wisata. Pun juga menurut Demartoto (2014) bahwa konsentrasi utama dari kawasan wisata di pedesaan adalah keaslian dari masyarakat setempatnya.

Mengembangkan pariwisata menjadi kegiatan yang menjanjikan, dan dibutuhkan keseriusan serta peran aktif dari banyak pihak, yang biasanya disebut insan pariwisata terdiri dari masyarakat, pihak swasta dan pemerintah. (Pitana \& Gayatri 2005). Para insan pariwisata memiliki peran dan kepentingan masing-masing yang berpengaruh terhadap kerjasama yang terjadi baik dalam bentuk suatu kebijakan, kesamaan visi dan misi, tugas pokok dan fungsi (Tupoksi) maupun aturan kelembagaan dan mempengaruhi keberhasilan pengelolaan maupun pengembangan dari wisata (Laksono, 2012).

Pelibatan masyarakat dalam pengelolaan kegiatan wisata ini dinilai menjadi pilihan tepat untuk bisa mengembangkan wisata pedesaan atau dalam ilmu pariwisata biasa disebut Community Based Tourism (CBT) atau Kepariwisataan Berbasis Komunitas (KBK). Menurut Ardika (2019) dalam konsep ini berusaha melibatkan kerjasama antara komunitas, pebisnis, dan pihak luar untuk mengembangkan pariwisata dan mendatangkan manfaat ekonomi, utamanya dengan menetapkan biaya pelayanan untuk aktivitas yang ditawarkan. Fakta saat ini menunjukkan bahwa CBT menjadi semakin populer sebagai alat pengembangan pertumbuhan yang berpihak pada penduduk miskin, dpergunakan sebagai 
sarana untuk mencapai tujuan, yaitu, sebagai katalis untuk memelihara kewirausahaan pedesaan yang berkembang di semua sektor ekonomi (Nair, 2015).

Pengembangan dan pengelolaan pariwisata yang baik pastilah akan mendatangkan beragam keuntungan bagi elemen-elemen yang terlibat di dalamnya. Karena faktanya banyak masyarakat desa di Indonesia memiliki kondisi ekonomi yang belum sejahtera, hasil Susenas pada Maret 2017 pun menunjukkan jumlah penduduk miskin sebanyak 17, 10 juta jiwa atau sebesar 13, 93 persen. Pariwisata membuka peluang pemerataan ekonomi yang berefek langsung kepada masyarakat. Tidak seperti dalam teori Trickle Down Effect yang menempatkan masyarakat di ujung terakhir penerima manfaat, pariwisata pedesaan berbasis komunitas menjadikan masyarakatlah yang menjadi tangan pertama dalam menerima manfaat. Hal ini akan menjamin kehidupan dan keberlanjutan masyarakat pedesaan yang lebih harmonis (Ardika, 2018). Namun sebagaimana kegiatan wisata pada umumnya, proyek kegiatan CBT tentu saja juga tetap membutuhkan perencanaan dan manajemen yang cermat. Proyek ini memerlukan adanya inovasi, target pemasaran yang tepat, dan pemantauan secara rutin guna menjamin keberhasilan dan kebermanfaatannya (Nair, 2015).

Selain pelibatan masyarakat secara langsung kedalam pengelolaan dan pengembangan wisata di pedesaan oleh komunitas warga, penting juga untuk diketahui bahwa masyarakat terutama pedesaan memiliki modal kehidupan yang mereka terapkan pada kehidupan sehari-hari. Salah satu modal yang mereka miliki ialah modal sosial yang terdiri dari norma, kepercayaan, dan jaringan yang telah terbentuk lama. Kepemilikan modal sosial ini ternyata bisa dimanfaatkan untuk mengembangkan wisata di pedesaan, kepercayaan masyarakat, nilai-nilai yang sudah tertanam dan berkembang norma-norma yang lama teguh dijadikan pedoman, kesenian, adat istiadat, serta kebiasaan-kebiasaan lainnya merupakan suatu modal yang dimiliki oleh masyarakat itu sendiri untuk mampu mengembangkan dan memajukan kawasan mereka sebagai tujuan wisata (Demartoto, 2014).

Diantara desa-desa yang ada di Kabupaten Boyolali, terdapat salah satu desa yang masyarakatnya memiliki antusias tinggi untuk mengembangkan potensi yang dimiliki melalui sektor wisata jenis agrowisata. Desa ini adalah Desa Senden dengan wilayah khusus terdapat di Dukuh Pasah. Desa Senden merupakan salah satu desa di wilayah Kecamatan Selo, Kabupaten Boyolali desa ini berada pada ketinggian $\pm 1.500 \mathrm{~m}$ dpl dan berada pada radius 3-4 km dari puncak Gunung Merbabu (Kecamatan Selo Dalam Angka, 2018).

Desa Senden dan khususnya wilayah Dukuh Pasah menawarkan suasana alam pedesaan yang alami, desa ini dapat ditempuh dalam waktu 1 jam dari pusat ibukota Boyolali. Sebagai desa di bawah lereng gunung, Desa Senden memiliki tingkat kesuburan tanah dan kondisi iklim yang baik untuk pengembangan kegiatan pertanian sayuran. Di desa ini pula mayoritas warga masyarakatnya berprofesi sebagai seorang petani sayur dan peternak sapi serta kambing. Berangkat dari kondisi itu, warga di Dukuh Pasah yang mayoritas seorang petani dan tergabung dalam berbagai kelompok tani membuat inovasi dalam hal pertanian, memanfaatkan keindahan alam sekitar dan juga kegiatan pertanian sayur yang biasa mereka lakukan akhirnya mereka memutuskan untuk membuat suatu kegiatan wisata berbasis agrowisata, dengan nama Argoayuningtani. Pengelolaan agrowisata ini dilakukan dengan tujuan untuk dapat menambah pendapatan selain dari hasil panen tanaman sayur, serta wujud dari para petani sayur untuk bisa mengembangkan teknik pertanian (Data observasi lokasi, 2020).

Dari pemaparan di atas, peneliti ingin mengetahui hubungan antara peran pemangku dengan modal sosial, hubungan anatara peran pemangku kepentingan dengan pengelolaan pariwisata berbasis komunitas, hubungan antara pengelolaan pariwisata berbasis komunitas dengan modal sosial, hubungan antara peran pemangku kepentingan dengan pengelolaan 
pariwisata berbasis komunitas melalui modal sosial serta hubungan antara peran pemangku kepentingan, modal sosial dan pengelolaan pariwisata berbasis komunitas secara bersamasama. Penelitian ini dianalisis menggunakan Teori Peran milik Biddle \& Thomas dan Teori Modal Sosial dari Fukuyama.

\section{METODE PENELITIAN}

Penelitian dilakukan di Dukuh Pasah Desa Senden Kecamatan Selo Kabupaten Boyolali. Penelitian ini menggunakan metode kuantitatif dengan pendekatan eksplanatif yang berguna untuk untuk menguji hipotesis hubungan antar variabel peran pemangku kepentingan dan modal sosial dengan pengelolaan pariwisata berbasis komunitas di agrowisata Argoayuningtani. Pada penelitian ini, penentuan sampel dilakukan dengan Non Probability Sampling jenis sampling jenuh atau yang juga disebut sensus. Metode ini dilakukan apabila jumlah populasi kurang dari 100 orang (Supriyanto dan Machfudz, 2010). Dalam penelitian ini sampel yang digunakan adalah seluruh anggota yang mengelola agrowisata Argoayuningtani berjumlah 60 orang. Teknik pengambilan data yang digunakan dalam penelitian ini adalah dengan angket atau kuesioner. Untuk pengujian instrumen kuisioner dilakukan uji validitas dan reliabilitas data. Analisis data menggunakan statistik korelasi product moment, korelasi parsial dan korelasi ganda yang dibantu dengan menggunakan SPSS 20.0.

\section{HASIL DAN PEMBAHASAN}

\section{A. Hasil}

\section{Profil Responden}

\subsection{Jenis Kelamin}

Berdasarkan hasil dari jawaban responden, berikut ini deskripsi responden menurut jenis kelamin:

Tabel 4.8 Deskripsi Responden Menurut Jenis Kelamin

\begin{tabular}{lcc}
\hline Jenis Kelamin & Jumlah Responden & Presentase \\
\hline Laki Laki & 23 & $38,3 \%$ \\
Perempuan & 37 & $61,7 \%$ \\
\hline Jumlah & 60 & $100,0 \%$
\end{tabular}

Sumber : Analisis Data Primer, 2020

Dari data di atas diperoleh bahwa dari 60 responden dalam penelitian ini terdiri dari 38,3\% laki-laki dan 61,7\% perempuan. Sebagian besar responden adalah perempuan, karena selain sebagai pengelola agrowisata mereka juga tergabung dalam Kelompok Wanita Tani (KWT).

\subsection{Usia}

Berdasarkan hasil dari jawaban responden, berikut ini deskripsi responden menurut jenis kelamin:

Tabel 4.9 Deskripsi Responden Menurut Usia

Usia Jumlah Responden Presentase




\begin{tabular}{lll}
\hline $20-30$ Tahun & 9 & $15,0 \%$ \\
$31-40$ Tahun & 31 & $51,7 \%$ \\
$41-50$ Tahun & 15 & $25,0 \%$ \\
$51-60$ Tahun & 5 & $8,3 \%$ \\
\hline Jumlah & 60 & $100 \%$
\end{tabular}

Sumber : Analisis Data Primer, 2020

Hasil penelitian di atas menunujkkan bahwa 51,7\% responden berusia 31 - 40 tahun. Usia ini merupakan usia produktif yang dibutuhkan untuk dapat mengelola agrowisata.

\subsection{Pekerjaan Utama}

Berdasarkan hasil dari jawaban responden, berikut ini deskripsi responden menurut pekerjaan:

Tabel 4.10 Deskripsi Responden Menurut Pekerjaan Utama

\begin{tabular}{lll}
\hline Pekerjaan & Jumlah Responden & Presentase \\
\hline Petani & 57 & $95,0 \%$ \\
Wiraswasta & 1 & $1,7 \%$ \\
Guru & 1 & $1,7 \%$ \\
PNS & 1 & $1,7 \%$ \\
\hline Jumlah & 60 & $100,0 \%$
\end{tabular}

Sumber : Analisis Data Primer, 2020

Data di atas menunjukkan bahwa sebagian besar responden sebesar 95,0\% memiliki pekerjaan utama sebagai petani, yang dibutuhkan dalam pengelolaan agrowisata.

\subsection{Pendidikan Terakhir}

Berdasarkan hasil dari jawaban responden, berikut ini deskripsi responden menurut pendidikan terakhir:

Tabel 4.11 Deskripsi Responden Menurut Pendidikan Terakhir

\begin{tabular}{lll}
\hline Pendidikan Terakhir & Jumlah Responden & Presentase \\
\hline Tidak Sekolah & 1 & $1,7 \%$ \\
SD & 22 & $36,7 \%$ \\
SMP & 17 & $28,3 \%$ \\
SMA & 16 & $26,7 \%$ \\
DIPLOMA & 4 & $6,7 \%$ \\
\hline Jumlah & 60 & $100 \%$ \\
\hline
\end{tabular}

Sumber : Analisis Data Primer, 2020

Hasil penelitian di atas menunjukkan bahwa $36,7 \%$ responden adalah berpendidikan SD. Hal ini sesuai dengan, data kependudukan yang menunjukkan bahwa mayoritas warga Desa Senden berpendidikan rendah. 


\section{Deskripsi Variabel}

\subsection{Peran Pemangku Kepentingan}

Variabel peran pemangku kepentingan diukur dengan 5 (lima) indikator dan 25 (dua puluh lima) item pertanyaan yaitu : keberfungsian pemangku kepentingan sebagai perencana, keberfungsian pemangku kepentingan sebagai pelaksana, keberfungsian pemangku kepentingan sebagai pengawas, keberfungsian pemangku kepentingan sebagai penjaga keberlanjutan program, dan keberfungsisan pemangku kepentingan sebagai penerima manfaat program.

Tabel 4.13 Peran Pemangku Kepentingan

\begin{tabular}{lll}
\hline Kategori & Frekwensi & Presentase \\
\hline Rendah & 30 & $50,0 \%$ \\
Sedang & 11 & $18,3 \%$ \\
Tinggi & 19 & $31,7 \%$ \\
\hline Total & 60 & $100,0 \%$ \\
\hline
\end{tabular}

Sumber : Analisis Data Primer, 2020

\subsection{Pengelolaan Pariwisata Berbasis Komunitas}

Variabel pengelolaan pariwisata berbasis komunitas diukur dari 9 (sembilan) indikator yaitu :tercapai tidaknya memperoleh perizinan pengelolaan wisata, tercapai tidaknya pembangunan di lokasi wisata, tercapai tidaknya melibatkan anggota sebagai pemandu wisata, tercapai tidaknya melibatkan anggota sebagai penyedia makanan dan minuman bagi pengunjung, tercapai tidaknya melibatkan anggota sebagai penyedia atraksi kepada pengunjung, tercapai tidaknya melibatkan anggota sebagai penyedia jasa transportasi, tercapai tidaknya memperoleh dana pengelolaan wisata, tercapai tidaknya memperoleh sarana pendukung wisata, tercapai tidaknya memperoleh prasarana pendukung wisata.

Tabel 4.15 Pengelolaan Pariwisata Berbasis Komunitas

\begin{tabular}{lll}
\hline Kategori & Frekwensi & Presentase \\
\hline Rendah & 22 & $36,7 \%$ \\
Sedang & 5 & $8,3 \%$ \\
Tinggi & 33 & $55,0 \%$ \\
\hline Total & 60 & $100,0 \%$
\end{tabular}

Sumber : Analisis Data Primer, 2020

Pengelolaan pariwisata berbasis komunitas ini terkategori tinggi yaitu yang dinyatakan responden sebesar 55,0\%, menunjukkan bahwa pengelolaan agrowisata telah tercapai dengan baik.

\subsection{Modal Sosial}

Variabel modal sosial diukur dari 3 (tiga) indikator dan 31 (tiga puluh satu) item pertanyaan yaitu : partisipasi dalam suatu jaringan, resiprositas, dan kepercayaan.

\section{Tabel 4.17 Modal Sosial}

\begin{tabular}{lll}
\hline Kategori & Frekwensi & Presentase
\end{tabular}




\begin{tabular}{llc}
\hline Rendah & 30 & $50,0 \%$ \\
Sedang & 13 & $21,7 \%$ \\
Tinggi & 17 & $28,3 \%$ \\
\hline Total & 60 & $100,0 \%$ \\
\hline
\end{tabular}

Sumber : Analisis Data Primer, 2020

Modal sosial ini terkategori rendah yang dinyatakan responden sebesar 50,0\%.

3. Hubungan Antar Variabel

3.1 Hubungan Antara Peran Pemangku Kepentingan dengan Modal Sosial

Menggunakan statistik korelasi product moment, hasil uji hipotesis I :

Ho : Tidak ada hubungan antara peran pemangku kepentingan dengan modal sosial

Ha : Ada hubungan antara peran pemangku kepentingan dengan modal sosial

Adalah sebagai berikut :

$$
\text { rxy }=0,995
$$

Hasil ini menunjukkan bahwa terdapat hubungan antara peran pemangku kepentingan dengan modal sosial. Hasil koefisien korelasi sebesar 0,995, ini menunjukkan ada hubungan yang signifikan dan sangat kuat antara variabel peran pemangku kepentingan dengan modal sosial. Jadi, dapat disimpulkan bahwa Ho ditolak dan Ha diterima yang berarti ada hubungan antara peran pemangku kepentingan dengan modal sosial.

\subsection{Hubungan Antara Peran Pemangku Kepentingan dengan Pengelolaan Pariwisata Berbasis Komunitas}

Hasil uji hipotesis II yaitu :

Ho

: Tidak ada hubungan antara peran pemangku kepentingan dengan pengelolaan pariwisata berbasis komunitas

$\mathrm{Ha} \quad$ : Ada hubungan antara peran pemangku kepentingan dengan pengelolaan pariwisata berbasis komunitas

Adalah sebagai berikut :

$$
\mathrm{rxy}=0,685
$$

Hasil ini menunjukkan bahwa ada hubungan antara peran pemangku kepentingan dengan pengelolaan pariwisata berbasis komunitas. Hasil koefisien korelasi sebesar 0,685 menunjukkan bahwa terdapat hubungan yang signifikan dan kuat antara variabel peran pemangku kepentingan dengan pengelolaan pariwisata berbasis komunitas. Jadi, dapat disimpulkan bahwa Ho ditolak dan Ha diterima yang berarti ada hubungan antara peran pemangku kepentingan dengan pengelolaan pariwisata berbasis komunitas.

\subsection{Hubungan Antara Peran Pemangku Kepentingan dengan Modal Sosial}

Hasil uji hipotesis III yaitu : 
Ho

: Tidak ada hubungan antara modal sosial dengan pengelolaan pariwisata berbasis komunitas

Ha : Ada hubungan antara modal sosial dengan pengelolaan pariwisata berbasis komunitas

Adalah sebagai berikut :

$$
\mathrm{rzy}=0,679
$$

Hasil ini menunjukkan bahwa ada hubungan antara modal sosial dengan pengelolaan pariwisata berbasis komunitas. Hasil koefisien korelasi sebesar 0,679 menunjukkan bahwa hubungan yang ada antara modal sosial dengan pengelolaan pariwisata berbasis komunitas tergolong kuat. Jadi, dapat disimpulkan bahwa Ho ditolak dan Ha diterima yang berarti ada hubungan antara modal sosial dengan pengelolaan pariwisata berbasis komunitas.

\subsection{Hubungan Antara Peran Pemangku Kepentingan dengan Modal Sosial}

Menggunakan statistik korelasi parsial, hasil uji hipotesis IV yaitu :

Ho

: Tidak ada hubungan antara peran pemangku kepentingan dengan pengelolaan pariwisata berbasis komunitas melalui modal sosial

Ha

: Ada hubungan antara peran pemangku kepentingan dengan pengelolaan pariwisata berbasis komunitas melalui modal sosial

Adalah sebagai berikut :

$$
\operatorname{rxy} \cdot z=0,121
$$

Menggunakan faktor uji variabel Intervening modal sosial dikatakan ada pengaruh terhadap hubungan variabel peran pemangku kepentingan dan variabel pengelolaan pariwisata berbasis komunitas apabila korelasi 2 variabel tersebut menghilang.

Terbukti dari hasil perhitungan memiliki signifikansi 0,360 yang artinya lebih besar dari signifikansi 0,000. Menunjukkan bukti bahwa, variabel peran pemangku kepentingan dengan pengelolaan hilang (tidak ada hubungan). Dari hasil ini menunjukkan bahwa, peran pemangku kepentingan dan pengelolaan pariwisata berbasis komunitas memiliki hubungan yang tidak murni, hubungan tersebut ada jika melalui modal sosial, jadi hipotesis yang menyatakan ada hubungan antara peran pemangku kepentingan dengan pengelolaan pariwisata berbasis komunitas melalui modal sosial terbukti.

\subsection{Hubungan Antara Peran Pemangku Kepentingan dengan Modal Sosial}

Menggunakan statistik korelasi ganda, hasil uji hipotesis V yaitu :

Ho

: Tidak ada hubungan secara bersama antara peran pemangku kepentingan, modal sosial, dan pengelolaan pariwisata berbasis komunitas

Ha : Ada hubungan secara bersama antara peran pemangku kepentingan, modal sosial, dan pengelolaan pariwisata berbasis komunitas

Adalah sebagai berikut : 
$R_{y . x z}^{2}$ dapat disebut sebagai koefisien determinasi ganda. Hal ini menyatakan besarnya variabel pengelolaan pariwisata berbasis komunitas diprediksikan oleh gabungan variabel peran pemangku kepentingan dan modal sosial. Dalam hal ini $R_{y \cdot x z}^{2}$ adalah 0,469 , maka dapat dikatakan bahwa 46,9\% dari varians pengelolaan pariwisata berbasis komunitas disebabkan oleh peran pemangku kepentingan dan modal sosial.

Sisa presentase varians, yaitu $100 \%-46,9 \%=53,1 \%$ masih dapat diterangkan oleh variabel lain. Untuk mengetahui adanya korelasi di dalam populasi antara ketiga variabel tersebut, maka dihitung $R_{y . x z}$

$$
\begin{aligned}
& R_{y \cdot x z}=\sqrt{0,469} \\
& R_{y \cdot x z}=0,685
\end{aligned}
$$

Hasil ini menunjukkan bahwa ada hubungan antara varibel peran pemangku kepentingan, pengelolaan pariwisata berbasis komunitas dan modal sosial di dalam populasi. Jadi hipotesis yang menyatakan ada hubungan secara bersama antara peran pemangku kepentingan, modal sosial, dan pengelolaan pariwisata berbasis komunitas terbukti.

\section{B. Pembahasan}

Pada penelitian ini peran pemangku kepentingan merupakan tugas utama yang harus dilakukan dan merupakan sebuah cerminan fungsi posisi seorang individu di masyarakat yang terlibat dalam kegiatan yang memiliki kepentingan dan saling mempengaruhi satu sama lain untuk keberhasilan proyek atau kegiatan tersebut.

Berdasarkan hasil penelitian menunjukkan bahwa tingkat peran pemangku kepentingan tergolong kedalam kategori rendah. Artinya warga yang merupakan para pemangku kepentingan dalam kegiatan agrowisata belum berperan secara maksimal.

Peran pemangku kepentingan agrowisata Argoayuningtani masih minim ditujukkan dari rendahnya respon responden pada indikator-indikator yang ada, dalam segi perencanaan, pelaksanaan, pengawasan, keberlanjutan kegiatan serta penerimaan manfaat. Jika dilihat dari latar belakang pendidikan yang sebagian besar responden berpendidikan rendah, peran perencanaan perizinan, perencanaan pendanaaan, perencanaan pengorganisasian, perencanaan penyedia sarana pendukung, perencanaan promosi menjadi tidak maksimal dikerjakan oleh para pemangku kepentingan tersebut. Hasil penelitian menunjukkan bahwa dalam hal perencanaan tersebut para responden kurang terlibat.

Adapun dalam segi pelaksanaan, sebagian besar responden kurang terlibat sebagai pelaksana perizinan, pelaksana pembangunan lokasi wisata, pelaksana atraksi penyambutan, pelaksana penyedia jasa transportasi, pelaksana penyandang dana. Dalam segi pengawasan, sebagaian besar pemangku kepentingan kurang terlibat dalam hal pengawas keamanan lingkungan, pengawas penggunaan dana, pengawas pembagian kerja, dan pengawas pembagian keuntungan. Lalu dalam segi keberlanjutan kegiatan, sebagian dari responden kurang terlibat dalam hal keberlanjutan pengorganisasian dan keberlanjutan pendanaan.

Apabila merujuk pada teori peran yang dikemukakan oleh Biddle dan Thomas, seseorang dikatakan berperan apabila mengambil bagian dari suatu interaksi sosial entah menjadi pelaku ataupun target yang dituju, dari interaksi itu akan menimbulkan harapan serta wujud nyata dari peran yang dimiliki. Seseorang yang dikatakan berperan ditandai juga dengan kedudukannya dalam suatu interaksi tersebut yang berbeda-beda sesuai dengan kemampuan dan pandangan orang lain serta untuk menyebut seseorang itu berperan, dapat dilihat dari derajat keterkaitan antara orang dan perilaku. 
Peran pemangku kepentingan agrowisata Argoayuningtani memang masih rendah dan masih belum merata, karena terdapat pengolongan peran yaitu ada yang memiliki peran utama dan ada yang memiliki peran pendukung. Peran utama didominasi oleh pemangku kepentingan laki-laki hal ini terbukti dari jumlah responden laki-laki lebih sedikit dari jumlah responden perempuan, dengan peran responden perempuan sebagai peran pendukung.

Fokus teori peran yang digunakan adalah perilaku yang muncul dalam suatu hubungan yang saling memengaruhi, norma dan wujud perilaku dalam peran. Saling mempengaruhi memberi makna adanya saling berhubungan secara timbal balik, sedangkan wujud perilaku dalam peran dapat diberi makna keterkaitan diri dalam peran yang dibawakan. Jika dikaitkan dengan konsep modal sosial yang memiliki unsur-unsur yakni yang pertama kuatnya jaringan yang terdiri dari partisipasi seseorang dalam suatu jaringan, resiprositas atau hubungan timbal balik dan kedua yakni kepercayaan, maka teori peran ini memiliki hubungan dengan konsep modal sosial yang digunakan. Hal ini ditunjukkan dengan nilai koefisien korelasi rxz $=0,995$.

Pengelolaan pariwisata berbasis komunitas pada agrowisata Argoayuningtani tergolong tinggi ditunjukkan dari tingkat ketercapaian dalam hal perizinan, ketercapaian melibatkan anggota sebagai penyedia makanan dan minuman, ketercapaian melibatkan anggota sebagai penyedia atraksi pengunjung serta tercapainya perolehan dana agrowisata. Pengelolaan pariwisata yang baik ini merupakan suatu anggapan dari para pemangku kepentingan yang merasa sudah melakukan dan mewujudkan hal $=$ hal yang harus ada di agrowisata mereka, namun faktanya pengelolaan yang baik ini dapat terjadi karena adanya peran pemangku kepentingan utama. Jika dikaitkan dengan teori peran di atas, konsep pengelolaan pariwisata berbasis komunitas memiliki hubungan yang terkategori kuat, dengan nilai koefisisen korelasi sebesar $\operatorname{rxy}=0,685$.

Berdasarkan hasil penelitian menunjukkan bahwa tingkat modal sosial tergolong kedalam kategori rendah. Pada penelitian ini, aspek modal sosial yang masih rendah ialah dalam hal keterlibatan pada agrowisata sedangkan dalam hal kepedulian dan kepercayaan pada agrowisata menunjukkan tingkatan yang baik.

Fokus teori modal sosial yang digunakan adalah modal sosial yang dapat berkontribusi dalam upaya pengembangan ruang ekonomi dan politik pada pengelolaan pariwisata berbasis komunitas. Upaya pengembangan ruang ekonomi dan politik terwujud pada keterlibatan dalam pengelolaan agrowisata, dalam hal ini keterlibatan anggota kelompok sebagai penyedia makanan dan minuman bagi pengunjung dan menyediakan atraksi penyambutan bagi pengunjung masuk dalam kategori tinggi, sedangkan aspek keterlibatan yang lain masih rendah. Selain keterlibatan, unsur penting dalam modal sosial ada pada kepedulian, yang dalam penelitian ini terwujud dari kepedulian menyumbang dana, menyediakan sarana dan prasarana pendukung untuk agrowisata yang terkategori tinggi.

Untuk dapat mewujudkan pengelolaan pariwisata berbasis komunitas yang baik juga diperlukan adanya rasa saling percaya antar satu sama lain, pada penelitian ini menunjukkan bahwa kepercayaan kepada organisasi dalam hal penggunaan dana, dan pembagian keuntungan tergolong tinggi, dengan hasil ini dinilai mempermudah suatu organisasi untuk mengelola suatu kegiatan, yang pada penelitian ini ada pada pengelolaan agrowisata Argoayuningtani.

Jika dikaitkan dengan konsep pengelolaan pariwisata berbasis komunitas yang merupakan suatu upaya melibatkan masyarakat secara aktif dalam setiap proses kegiatan yang bertujuan untuk mencapai tujuan yang ditentukan serta memberikan kebermanfaatan bagi pelakunya maka, teori modal sosial memiliki hubungan dengan konsep pengelolaan pariwisata berbasis komunitas yang digunakan. Hal ini ditunjukkan dengan nilai koefisien korelasi rzy $=0,679$. 
Peran dari para pemangku kepentingan memiliki hubungan yang penting dalam hal pengelolaan pariwisata berbasis komunitas, namun dalam penelitian ini hubungan yang tercipta membutuhkan adanya perantara,yakni modal sosial. Keberadaaan modal sosial menunjukkan bahwa hubungan yang tercipta diantara dua variabel tersbut adalah hubungan yang tidak murni. Hasil dari penelitian ini menunjukkan nilai korelasi parsial sebesar rxy.z $=0,121$.

Berdasarkan hasil penelitian, menunjukkan bahwa terdapat hubungan yang terjadi secara bersama-sama antara peran pemangku kepentingan dan modal sosial dengan pengelolaan pariwisata berbasis komunitas, dengan nilai korelasi ganda sebesar $R_{y \cdot x z}=$ 0,685 .

\section{PENUTUP}

Peran pemangku kepentingan belum maksimal, terutama dalam hal perencanaan, pelaksanaan, pengawasan, dan keberlanjutan kegiatan. Ini menunjukkan bahwa pemangku kepentingan belum mampu mengemban tugas utamanya pada pengelolaan agrowisata Argoayuningtani.

Pemangku kepentingan sebagai orang yang terlibat dalam suatu kegiatan, memiliki kepentingan dan saling memengaruhi satu sama lain, ini menunjukkan adanya hubungan timbal balik yang membutuhkan adanya rasa saling percaya antar sesama. Keterlibatan, hubungan timbal balik, dan kepercayaan merupakan komponen modal sosial. Modal sosial yang dimiliki pemangku kepentingan tidak begitu erat, artinya keberlangsungan hubungan antar individu-individu belum maksimal.

Dalam pengelolaan nampak pada kurangnya keterlibatan dalam meyediakan sarana dan prasarana pendukung, sehingga target dalam hal sarana dan prasana agrowisata kurang tercapai. Jika dikaitkan dalam hal kepercayaan, para pemangku kepentingan percaya pada penggunaan dana yang terkumpul baik dari anggota maupun dari pengunjung agrowisata yang digunakan sebagai mana mestinya, demikian juga dengan pembagian keuntungan, pemangku kepentingan percaya kepada pengelola bagian keuangan. Dalam hal kepedulian yang ditunjukkan dengan pengelolaan pariwisata berbasis komunitas secara keseluruhan sudah dianggap baik.

Peran pemangku kepentingan berhubungan dengan pengelolaan jika terdapat modal sosial. Modal sosial disini merupakan perantara hubungan diantara mereka. Dalam hubungan ini keberadaan modal sosial menjadi penting untuk dapat mewujudkan adanya hubungan antar keduanya, sehingga dapat dikatakan bahwa hubungan antara peran pemangku kepentingan dengan pengelolaan pariwisata adalah hubungan yang tidak murni.

Akan tetapi, hubungan peran peamngku kepentingan, modal sosial dan pengelolaan pariwisata memiliki hubungan di dalam populasi sehingga ketiga variabel tersebut memiliki hubungan secara bersama-sama. Pada penelitian ini,variabel pengelolaan pariwisata sebenarnya masih dapat dijelaskan oleh variabel lain selain variabel peran pemangku kepentingan dan modal sosial.

Berdasarkan hasil penelitian yang diperoleh dan kesimpulan ada beberapa saran yang dapat dijadikan bahan pertimbangan dan masukan bagi pihak-pihak yang terkait.

\section{Bagi Pengelola Agrowisata}

Meningkatkan lagi peran aktif dan keterlibatan dari pemangku kepentingan dengan melakukan pembagaian peran yang lebih jelas dan terstruktur melalui 
pertemuan rutin maupun pelatihan-pelatihan. Meningkatkan modal sosial dalam hal keterlibatan para pemangku kepentingan sehingga dapat meningkatkan kerjasama antar pemangku kepentingan, selain itu perlu adanya peningkatan dalam hal pengelolaan seperti pada ketersediaan sarana dan prasarana yang ditambah lagi dan tak lupa untuk selalu dijag dan dirawat, agar senantiasa dalam keadaan tersedia dan dalam kondisi baik bagi para pengunjung yang datang.

2. Bagi Peneliti Lain

Melihat hasil penelitian dan analisis, besaran tingkatan peran pemangku kepentingan, modal sosial masih rendah. Perlu dilakukan penelitian lebih lanjut dengan menggunakan indikator maupun variabel yang berbeda dari penelitian ini yang dinilai masih berhubungan dengan pengelolaan pariwisata berbasis komunitas, sebab masih ada variabel lain yang mempengaruhi pengelolaan pariwisata berbasis komunitas.

\section{DAFTAR PUSTAKA}

Ardika.I Gede. 2018. Kepariwisataan Berkelanjutan: Rintis Jalan Lewat Komunitas. Jakarta: Kompas Gramedia.

Demartoto, Argyo. dkk. 2014. Habitus Pengembangan Pariwisata: Konsep Dan Aplikasi. Surakarta : Sebelas Maret University Press.

http://www.bps.go.id/wisatawan-mancanegara-yang-datang-ke-indonesia-menurutkebangsaan-2015-2019.html (Diakses 08 Februari 2019 Pukul 21.00).

Kementrian Pariwisata. 2016. Panduan Pembentukan Desa Wisata. Jakarta:Kemenpar.

Laksono R. 2012. Identifikasi karakteristik berbagai pengelolaan wisata alam di Kabupaten Bogor. Skripsi. Bogor: Institut Pertanian Bogor.

Nair. Vikneswaran dan Amran Hamzah. 2015. "Successful community-basedtourism approaches for ruraldestinationsThe Asia Pacific experience". Worldwide Hospitality and Tourism Themes. Emerald Group Publishing Limited. Vol. 7 No. 5, 2015. pp. 429-439

Pitana, I Gde, dan Putu G, Gayatri. 2005. Sosiologi Pariwisata. Yogyakarta : Andi.

Rizkianto, Neno, dan Topowijoyo. 2018. "Penerapan Konsep Community Based Tourism Dalam Pengelolaan Daya Tarik Wisata Berkelanjutan (Studi Pada Desa Wisata Bangun,Kecamatan Munjungan, Kabupaten Trenggalek).” administrasibisnis.studentjournal.ub.ac.id 58:20-26.

Supriyanto, Achmad Sani. dan Masyhuri Machfudz. 2010. Metodologi Riset: Manajemen Sumberdaya Manusia. Malang: UIN-Maliki Press. 